\title{
Correction to letter on VMMC by Professor Peter S Millard
}

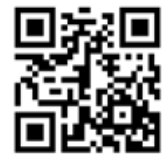

To the Editor: I thank Professor Millard for his interest $^{[1]}$ in my article $^{[2]}$ on some ethical aspects surrounding voluntary medical male circumcision (VMMC). He presents Table 1 (study data), which has a range for the Kenyan relative risk reduction (RRR) and the number needed to prevent HIV infection (NNT) but he presents no range of values for South Africa and Uganda. In addition, he does not present the point estimate and 95\% confidence intervals for the RRR and NNT. Finally, he does not show how the RRR and NNT were calculated. By him presenting Table 1 in this way, one cannot readily make like for like comparisons.

I provide here, so that Table 1 can be interpreted in a more informed manner, (see Table 2 and the supplementary appendix (available at: http://dx.doi.org/10.7196/ sajbl.413), the source of my data ${ }^{[3]}$, and the methods used for calculation ${ }^{[4,5]}$ (I do not include $95 \%$ confidence intervals so as to facilitate comparison of the two tables). The source of my data is a meta-analysis which is generally regarded as the highest level of evidence ${ }^{[6]}$. The two meta-analyses ${ }^{[3,7]}$ on the three VMMC randomised controlled trials ${ }^{[8-10]}$ used rigorous methodology to directly assess the three trials. On the

Table 1. From Peter S Millard ${ }^{[1]}$

\begin{tabular}{llll}
\hline Study location & $\begin{array}{l}\text { HIV incidence in } \\
\text { control group (\%) }\end{array}$ & $\begin{array}{l}\text { Relative risk } \\
\text { reduction (\%) }\end{array}$ & $\begin{array}{l}\text { Number needed to } \\
\text { prevent HIV infection }\end{array}$ \\
\hline Kenya & 4.2 & $53-60$ & $40-47$ \\
South Africa & 2.1 & 60 & 80 \\
Uganda & 1.3 & 50 & 149
\end{tabular}

other hand, Table 1 is central to Professor Millard's correspondence; however he does not provide sufficient information on how he came up with this table. Table 1 inflates the NNT for South Africa and Uganda and deflates the Kenyan NNT creating the notion that NNT varies widely and is unstable.

Professor Millard writes: 'The RRR is stable over wide variations in the risk of the population being studied, while the NNT varies widely with risk.' In brief, NNT $=1 /$ (RRR $x$ control event rate) ${ }^{[4,5]}$. Thus if the RRR is unstable, then the NNT will also be unstable. Please see the additional file (an infographic) for further details. (available at: http://dx.doi. org/10.7196/sajbl.414

Scientific endeavour is advanced by discussion; I welcome Professor Millard's response, more so regarding his methodology and presentation style for Table 1. I hope he can make his methods publicly available for scrutiny, as I have done for mine.

\section{Gwinyai Masukume}

Division of Epidemiology and Biostatistics, School of Public Health, Faculty of Health Sciences, University of the Witwatersrand, Johannesburg, South Africa parturitions@gmail.com

\section{References}

1. Millard PS. The ethics of claiming a $60 \%$ reduction in HIV acquisition from voluntary medical male circumcision. S Afr J BL 2014;7(2):78. [http://dx.doi. org/10.7196/sajbl.329]

2. Masukume $\mathrm{G}$. The ethics of claiming a $60 \%$ reduction in HIV acquisition from voluntary medical male circumcision. S Afr J BL 2014;7(1):4. [http://dx.doi. org/10.7196/sajbl.313

3. Mills E, Cooper C, Anema A, Guyatt G. Male circumcision for the prevention of heterosexually acquired HIV infection: A meta-analysis of randomized trials involving 11,050 men. HIV Med 2008;9(6):332-335. [http://dx.doi.org/10.1111/ j.14681293.2008.00596.x]

4. Pai M, Filion K. McGill University. An overview of measurements in epidemiology [VER 3, 2007]. 2007. http://www.teachepi.org/documents/courses/ An\%200verview\%20of\%20Measurements\%20 in\%20Epidemiology.pdf (accessed 10 November 2014).

5. Barratt A, Wyer PC, Hatala R, et al. Tips for learners of evidence-based medicine: 1. Relative risk reduction, absolute risk reduction and number needed to treat. CMAJ 2004;171(4):353-358 [http://dx.doi.org/10.1503/cmaj.1021197]

6. Oxford Centre for Evidence-based Medicine Levels of Evidence (March 2009). 2009. http:// www.cebm.net/oxford-centre-evidence-basedmedicine-levels-evidence-march-2009/ (accessed 10 November 2014).

7. Siegfried N, Muller M, Deeks JJ, Volmink J. Male circumcision for prevention of heterosexual acquisition of HIV in men. Cochrane Database Syst Rev 2009;2:CD003362. [http://dx.doi. org/10.1002/14651858.CD003362.pub2]

8. Auvert B, Taljaard D, Lagarde E, et al. Randomized, controlled intervention trial of male circumcision for reduction of HIV infection risk: The ANRS 1265 Trial. PLoS Med 2005;2: e298. [http://dx.doi. org/10.1371/journal.pmed.0020298]

9. Gray RH, Kigozi G, Serwadda D, et al. Male circumcision for HIV prevention in men in Rakai, Uganda: A randomised trial. Lancet 2007;369(9562):657-666. [http://dx.doi.org/10.1016/S0140-6736(07)60313-4]

10. Bailey RC, Moses S, Parker CB, et al. Male circumcision for HIV prevention in young men in Kisumu, Kenya: A randomized controlled trial. Lancet 2007;369(9562):643-656. [http://dx.doi. org/10.1016/S0140-6736(07)60312-2]

S Afr J BL 2015;8(1):7. DOI:10.7196/SAJBL.367

Table 2. For comparison with Table 1.

\begin{tabular}{lllllll}
\hline Study location & $\boldsymbol{n}$ & Intervention & Control & $\begin{array}{l}\text { Absolute risk } \\
\text { reduction (\%) }\end{array}$ & $\begin{array}{l}\text { Relative risk } \\
\text { reduction (\%) }\end{array}$ & $\begin{array}{l}\text { Number needed to } \\
\text { prevent HIV infection }\end{array}$ \\
\hline Kenya & 2780 & $19 / 1388^{*}$ & $46 / 1392$ & 1.9 & 59 & 52 \\
South Africa & 3128 & $20 / 1546$ & $49 / 1582$ & 1.8 & 58 & 55 \\
Uganda & 4996 & $22 / 2474$ & $45 / 2522$ & 0.9 & 50 & 111
\end{tabular}

*19/1388 means that there were 19 HIV positive participants out of 1388 participants in the intervention (VMMC) arm of the trial (see supplementary appendix for calculations). 